Jurnal PINUS: Jurnal Penelitian Inovasi Pembelajaran, 7 (1), 2021, 43 - 52

Available online at: $\underline{\text { http://ojs.unpkediri.ac.id/index }}$

DOI: https://doi.org/10.29407/pn.v7i1.16392

\title{
Rectoverso Education And Technology: Digital Track Of Adaptive Covid-19 Civic Education Learning Dedy Ari Nugroho ${ }^{1}$ and Irawan Hadi Wiranata ${ }^{2}$ \\ 12dedy.nugroho@ulm.ac.id, ${ }^{2}$ wiranata@unpkdr.ac.id Pancasila and Civic Education Study Program Faculty of Teacher Training and Education, ${ }^{1}$ Lambung Mangkurat University, Banjarmasin \\ ${ }^{2}$ Universitas Nusantara PGRI Kediri
}

\begin{abstract}
Abstrak
Pendidikan dan kemajuan teknologi adalah dua hal yang tidak bisa dipisahkan. Keduanya saling menopang dan bersinergi menuntaskan persoalan. Salah satu bagian penting dari kemajuan adalah guru dan sistem pendidikan yang terbuka pada perubahan. Guru dan sistem pendidikan dilarang tenggelam pada perubahan. Perkembangan teknologi adalah memontum untuk bergerak bersinergi dalam kemasan pendidikan baru yang adaptif terhadap kegiatan digital. Best practice pempelajaran adaptif teknologi telah ditunjukkan oleh guru, dalam rangka mengembangkan kebaruan kemasan pendidikan menyongsong era society 5.0. Guru PPKn sebagai guru mata pelajar aplikatif dan progresif memegang peran penting di era digital. Generasi bangsa perlu dibekali pengethuan, keterampilan, dan nilai hidup yang luhur. Guru PPKn di era society 5.0 perlu memfasilitasi pembelajar, tidak hanya untuk berkarya tetapi juga menjadi pengaruh bagi generasi sesamanya melalui jejak digital yang inspiratif dan kaya akan nilai kebangsaan. Pembelajar masa kini tidak hanya terhubung dengan kelasnya, tetapi mereka terhubung dengan dunia.
\end{abstract}

Kata kunci : Kewarganegaraan digital, pembelaran, Teknologi

\begin{abstract}
Education and technological progress are two things that cannot be separated. Both support each other and work together to solve problems. An important part of progress is that teachers and education systems are open to change. Teachers and the education system must not sink into change. The development of technology is a momentum to move in synergy in new educational packages that are adaptive to digital activities. The best practice of technology adaptive learning has been shown by the teacher, in order to develop the novelty of educational packaging to meet the era of society 5.0. Civic Education teachers as teachers of applicable and progressive subjects play an important role in the digital era. The nation's generation needs to be equipped with knowledge, skills, and noble life values. The result of the civics teachers in the era of society 5.0 need to facilitate learners, not only to work but also to be an influence for other generations through digital footprints that are inspiring and rich in national values. Today's learners are not only connected to their class, they are connected to the world.
\end{abstract}

Keyword: Civic, Education, Technology

Peer reviewed under responsibility of Universitas Nusantara PGRI Kediri. (C) 2021 Dedy Ari Nugroho, Irawan Hadi Wiranata

This is an open access article under the CC BY-SA license

( https://creativecommons.org/licenses/by-sa/4.0/ ) 


\section{INTRODUCTION}

Fakta Education cannot be ignored, even though the pandemic is still a challenge. Education must be developed so that the nation's generation can consciously show their abilities. The current state of education creates opportunities as well as challenges for every society. Not only teachers, but families, and communities are the main actors in guarding quality education for every child.

Education now has to innovate in presenting learning that contains the latest elements but with limited conditions. Education ideally presents knowledge with one of its outputs presenting efforts to change attitudes. Pancasila and Citizenship Education is a progressive scientific field, requiring every implementer to be sensitive to developing issues. Every teacher and student should be able to direct the interactive learning process and discuss contemporary issues to determine the level of critical thinking and attitude that will be carried out.

Citizenship Education (Civic Education) or Civic: has many meanings and terms. Not much different from this understanding, Muhammad Numan Somantri, formulated: "The definition of Civics as a Citizenship Science which discusses human relations with: (a) humans in organized associations (social, economic, political organizations); (b) individuals with the state" (Ubaedillah, 2015). Long before that, Edmonson (1958) stated that "the meaning of civics has always been defined as a study of government and citizenship related to the obligations, rights, and privileges of citizens. This understanding shows that civics is a branch of political science, as stated in the Dictionary of Education" (Ubaedillah, 2015).

The learning orientation of Pancasila and Citizenship Education has more challenges, because learning must at least achieve aspects of knowledge, skills, and dispositions. That is, Pancasila and Citizenship education does not only provide an understanding of theoretical aspects, but also provides skills in applying any existing knowledge, and has life values that can be cultivated in accordance with the principles of community, nation and state life.

The Covid-19 virus has plagued and infected millions of people in the world, including Indonesia. The ongoing pandemic does not only affect the health sector, but also almost all areas of life. The Covid-19 virus has triggered chaos in various fields of life globally, including the field of education. Face-to-face teaching and learning activities in schools are no longer carried out and replaced with online learning. This policy was implemented to reduce the spread of the Covid-19 virus. Efforts to prevent the spread of Covid-19 in the school environment are in line with the government's appeal, namely to organize online learning at home. Online learning gives birth to logical consequences, both for teachers, parents, and students. Online learning brings benefits as well as challenges for teachers, parents, and 
students. Weaknesses that we can find in students include: (1) lack of motivation and concentration in participating in learning, (2) less responsibility for assignments given by the teacher, as one example is the attitude of ignoring material and assignments, while doing assignments but being collected more slow even after the deadline.

The condition of education in the pandemic era is indeed unpredictable. But this condition can be overcome with various policies and innovations. Limitations of distance and access make teachers and education providers have to involve various elements to create meaningful and quality learning. One of them is the use of technology as an element in packaging the latest education and staying safe obeying the rules in the midst of a pandemic.

According to Warsita (2008) information technology is a means and infrastructure (hardware, software, useware) systems and methods for obtaining, transmitting, processing, interpreting, storing information, organizing, and using data meaningfully. The same thing was also expressed by Lantip and Rianto (2011) information technology is defined as science in the field of computer-based information and its development is very rapid. Hamzah B. Uno and Nina Lamatenggo (2011) also stated that information technology is a technology used to process data. Processing includes processing, obtaining, compiling, storing, manipulating data in various ways to produce quality information, namely information that is relevant, accurate, and timely.

Technological progress should provide space for the growth and development of education. Technology will provide a wide space for the learning process to achieve its goals, both in terms of knowledge or skills, as well as the value of life. The use of technology in Pancasila and Citizenship Education will help achieve these three aspects, namely knowledge, skills, and disposition if properly packaged and directed wisely.

There are strategies that need to be implemented to ensure the use of technology in Pancasila and Citizenship Education can achieve the goals set. The planned strategy will certainly affect the success of the specified program. Therefore, it is very important for every education system to plan carefully regarding what strategies will be implemented.

Bryson (2004) describes the cycle of strategic planning that can be carried out by each education system/school in achieving program success. The strategic planning cycle given by Bryson is called ABC strategic planning. Bryson (2004) means that $A$ is the first stage that explains the state of an education/school system seeking to find out its position, duties, and functions, as well as the conditions being faced. Furthermore, B is a situation where the education/school system determines the direction and goals to be achieved, including determining the program to be carried out. Finally, $\mathrm{C}$ is the state of the organization when determining steps, tactics, or ways that can be done to determine the success of 
Jurnal PINUS: Jurnal Penelitian Inovasi Pembelajaran, 7 (1), 2021, Dedy Ari Nugroho, Irawan Hadi Wiranata

the goals or programs previously set. In $\mathrm{ABC}$ strategic planning, there are also activities to formulate, clarify, and solve problems of a program. Bryson (2004) describes the ABC strategic planning cycle in a chart, as follows.

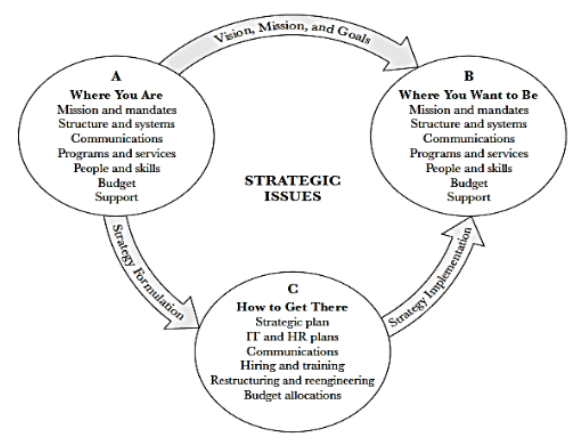

Figure 1. ABC Strategic Planning Cycle (Bryson, 2004)

Referring to the strategy above, technology can be directed as a provider of learning resources that can be managed so that it can run as needed. Technology in this case will be directed one of them by making it a media provider of learning media. With regard to learning media that is packaged using the latest technology, several benefits will be obtained. Regarding the benefits of learning resources, Sudjana (2007) conveys the following: First, learning resources are designed to assist the teaching and learning process. Second, the learning resources that are used can provide convenience to a person in learning, in the form of all learning resources found in the surrounding environment. Furthermore, it can be concluded that the benefits of learning resources are as follows: 1) Learning resources can be used as a means of obtaining information related to a science, 2) Learning resources can be used to facilitate the student learning process, 3) Provide an overview of objects that are abstract and difficult to understand, 4) Provide information about the development of a science.

As a learning resource, technology can be directed to collaborate with social media which is currently very familiar to learners. Some examples of social media that teachers can use to implement Pancasila and Citizenship Education materials and values are Instagram, WhatsApp, Twitter, Facebook, YouTube, and so on. This article will present fact-based data regarding the digital/technology footprint carried out by Pancasila and Citizenship Education teachers.

\section{METHOD}

Penelitian type of research used in this scientific paper is descriptive qualitative research, because it describes the object under study (people, institutions or others) based on facts. According to Denzin and Lincoln (Moleong, 2006) states that qualitative research is research that uses a natural setting, with the intention of interpreting phenomena that occur and is carried out by involving various existing methods. The research in this scientific paper was conducted in Sukoharjo Regency, Central Java Province, in collaboration with literacy studies on best practice learning Pancasila and Citizenship Education. Meanwhile, the research time in this scientific paper was carried out for eight months, from February 2021 to April 2021. The sampling technique used in this study was snowball sampling. According to Sugiyono (2010) Snowball sampling is a technique for determining 
Jurnal PINUS: Jurnal Penelitian Inovasi Pembelajaran, 7 (1), 2021, Dedy Ari Nugroho, Irawan Hadi Wiranata

samples that are initially small in number, then enlarge. In accordance with the form of qualitative research and also the type of data source used, the data collection instruments that will be used in this study include: interviews (interviews), observations (observations), and document analysis. The validity of the data in this study was carried out using data triangulation. According to Sutopo (2002) argues that triangulation of data, is that the same or similar data will be more stable, the truth can be extracted from several different data sources. In addition to using data triangulation, in determining the validity of the data in this study, review informants were also used. The data analysis used in this study refers to the opinion of Sutopo (2002). Sutopo (2002) argues that "in the process of data analysis there are 4 components that must be understood by every qualitative researcher. The four components include: (1) data collection, (2) data reduction, (3) data presentation, (4) drawing conclusions or verification. Analysis of the data in this study in detail can be observed in the following chart.

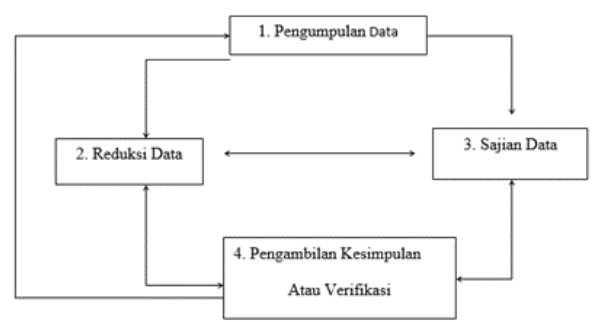

Figure 2. Interactive Analysis Model Miles and Hubberman (1992)

\section{RESULT}

Berdasarkan Education and technology are two things that are interrelated and mutually benefit each other. Moreover, education that is run in the midst of a pandemic certainly requires more facilities to implement quality education. The results of the research on the use of technology in civics learning were obtained from the results of observations, interviews, and document studies that were relevant to the research. In general, this is evidenced by the many innovations carried out by civics teachers to respond to the progress of the times, with one of them using applications available on smartphones. The implementation of Pancasila and Citizenship Education learning can be done by collaborating using technology. There are 4 findings that can be published in this journal article. The findings in question include:

\section{A. Demands for Pancasila and Citizenship Education}

This research is relevant to the research entitled The Role Of Technology In Learning In The Covid-19 Pandemic from Hanifah (2020). The results and conclusions in this paper show that technology has an important role in the implementation of learning, especially during the Covid-19 pandemic like today. Technology plays a role as a medium in making interactions between educators and students in the implementation of online learning. In addition, technology also plays a role in facilitating educators to deliver learning material so that learning continues even though it is not done face to face. 
Jurnal PINUS: Jurnal Penelitian Inovasi Pembelajaran, 7 (1), 2021, Dedy Ari Nugroho, Irawan Hadi Wiranata

1. Today's Educational Demands in a Global Dimension

Education is an important factor in shaping the nation's character. Through advanced education, learners' access is no longer limited to the classroom but more broadly connected to the world. Proficiency in technology, academic competence, and global social values are important aspects to advance civilization. The demands of Pancasila and Citizenship education, in the global context, are directed to adopt the $4 \mathrm{C}$ principles in learning, including:

a. Critical Thinking

Learning Pancasila and Citizenship Education is held by presenting various data, issues, news, and facts that are related and relevant to the subject matter. Students are directed to think critically about the phenomenon and try to provide a solution.

b. Communication

(Communication Ability)

The implementation of Pancasila and Citizenship Education is directed to train and develop good and correct communication skills, in carrying out patterns of interaction with the community. Good communication will produce the right information, the right information will make people smarter, this ability is also needed by every citizen in carrying out the life of society, nation and state.

c. Collaboration

The implementation of Pancasila and Citizenship Education is carried out with a collaborative system, how each education actor is able to cooperate with various parties. This collaboration will encourage new facilities and new innovations.

d. Creativity (Creativity)

Creativity is one of the goals to be achieved in today's learning. No exception in the implementation of Pancasila and Citizenship Education, creativity to present data, information, and learning outcomes to the community in a straightforward manner to achieve the goals of society, nation and state.

The description above provides a new reference regarding the importance of $21 \mathrm{st}$ Century competencies for the sustainability of today's generation. By applying and paying attention to each of the 4C values, it is hoped that Pancasila and Citizenship education can be carried out meaningfully and create an adaptive learning experience.

2. Educational Demands in the Context of Pancasila and Citizenship Education 
Jurnal PINUS: Jurnal Penelitian Inovasi Pembelajaran, 7 (1), 2021, Dedy Ari Nugroho, Irawan Hadi Wiranata

David Kerr, in his journal Citizenship Education in the Curriculum: An International Review. Provide references for civic education learning by categorizing it into minimum and maximum levels.

a. The continuum or minimal level emphasizes more on instructional activities, memorizing material, doing practice questions, and activities that are dominant in fostering one's cognitive aspects.

b. The continuum or maximum level is more directing the learner to a participatory learning experience, directly involved in community projects.

The demands for Pancasila and Citizenship education above should be directed at activities that are close to the maximum quantum, with the practice of citizenship in it. Learners are not only limited to the theoretical context in the classroom but also reach out to real life in society.

\section{B. The Urgency of Technology in Civics Learning}

The development of human civilization is accompanied by the development of ways of delivering information, hereinafter known as (Information Technology). At first, Information Technology was developed by humans in prehistoric times and served as a system for recognizing the forms they knew, they described the information they got on cave walls, about hunting and their prey. Until now information technology continues to grow but the delivery and form is more modern. According to Bambang Warsita (2008:135) information technology is the means and infrastructure (hardware, software, useware) systems and methods for obtaining, transmitting, processing, interpreting, storing, organizing, and using data meaningfully.

Some of the urgency of technology in education can be detailed as follows.

1. The principle of technology is to make it easier for humans to carry out various activities. This is then an important consideration why technology needs to guard the progress of education.

2. Community accessibility to learning materials can be presented digitally through technological advances.

3. Learning media The word media is the plural form of the word medium. Medium can be defined as an intermediary or introduction to the occurrence of communication from the sender to the receiver (Heinich et.al, 2002)

4. Administrative tool: Technology can also be used as an administrative tool. One of the benefits of digital technology is as an improvement in the 
Jurnal PINUS: Jurnal Penelitian Inovasi Pembelajaran, 7 (1), 2021, Dedy Ari Nugroho, Irawan Hadi Wiranata

effectiveness of organizing educational institutions

5. Learning resources: digital technology can help teachers to produce learning materials and enable them to spend time with students

Some of the descriptions above provide references to the importance of technology in education. In the implementation of learning the subjects of Pancasila and Citizenship Education, technology plays an important function as a means of delivering material, making material more meaningful through digital activities. For example, some teachers use the project citizen method to give video-based assignments for public service advertisements related to the material provided.

C. Best Practice for Technologybased Civics Learning

The use of technology in Civics learning has been widely carried out by every teacher. The pandemic requires teachers to innovate and utilize multiple resources to carry out meaningful learning. Based on the data from the research conducted, there are several activities of Civics teachers who successfully involve technology in it. The following are some of the implementations that have been carried out.

1. Utilization of Social Media as part of Learning

Technological progress is marked by the number of students' access to social media. Instagram, facebook, twitter, tiktok, and so on. But this is not to be eliminated but we help direct it, according to learning needs. Creating public service advertisements and posting them will make students become influencers for their social media friends.

2. Utilization of face-to-face applications online

Material affirmation and control, can be done using an online application platform. For example, using zoom cloud meetings, google meet, whatsapp, and so on, while still providing meaningful learning, by first compiling contextual discussion concepts while online.

3. Use of Voice Media (Podcasts and Voice Notes)

Podcast is a learning media that can be applied in the context of Civics learning. Podcasts containing voice messages tend to be long in duration and are easily accessible to learners. Likewise, Voice Note is the only one available on WA and can be applied to measure the communication skills of learners.

4. Making learning videos and uploading them to youtube

Video learning is an alternative that is considered easily accessible to today's learners. Teachers are required to be innovative by making videos as interesting as possible with short 
material content that is included in the core of the discussion.

The explanation above is a successful practice of Civics teachers in implementing technology-based learning. Various kinds of activities can be accommodated and facilitated with access to the created technology. The various facilities used are expected to be able to be reinnovated and become an inspiration for every education actor in carrying out learning.

\section{CONCLUSION}

Berdasarkan The conclusions in this study include 3 things, firstly related to the Civics learning process that must be adapted to the demands of today's education, the 21st Century. The activities carried out refer to competencies that will make it easier for today's generation to be wise in facing the progress of the times. The second relates to the urgency of using technology in learning, it will make it easier for everyone to carry out learning at a certain distance. The third relates to the successful practice of Civics teachers in implementing technology-based learning. The use of videos, podcasts, LMS, and other means actually makes it easier for teachers to deliver material and still appreciate students by conveying a lot of technology-based meaningful things.

\section{REFERENCE}

Bryson, John. M. (2004). Perencanaan Strategis bagi Organisasi Sosial. Yogyakarta. Pustaka Pelajar.
Hanifah, Unik. (2020). Teknologi dalam Pembalajaran adaptif Covid-19. Jurnal Penelitian dan Kajian Sosial Keagamaan.

Heinich, R., et. al. (2002). Instructional Media and Technologies for Learning. New Jersey: Prentice Hall, Englewood Cliffs.

Lestari, Sudarsri. (2018). Peran Teknologi Dalam Pendidikan Di Era Globalisasi. Edureligia; Jurnal Pendidikan Agama Islam, 2(2): 9596.

https://doi.org/10.33650/edureligia.v $2 \mathrm{i} 2.459$.

Miarso, Yusufhadi. (2016). Menyemai Benih Teknologi Pendidikan. Jakarta: Prenadamedia Group,. https://books.google.co.id/books?id $=$ rhVNDwAAQBAJ \&printsec $=$ front cover \&dq=buku

+menyemai+benih+teknologi+pendi dikan\&hl=id\&sa $=$ X\&ved $=2$ ahUKE wiTh_ez--

3sAhWDILcAHfoLCjgQ6AEwAHo ECAUQAg\#v=onepage \&q=buku menyemai benih teknologi pendidikan $\& \mathrm{f}=$ false .

Padmini, Kristiana Hesti, and Brigitta Putri Atika Tyagita. (2015). Teknologi Pendidikan Sebagai Pembelajaran Kompetitif Untuk Meningkatkan Prestasi Siswa: Studi Kasus Di Salah Satu SMA di Salatiga. In Prosiding Seminar Nasional Pendidikan, 60. Surakarta,. https://media.neliti.com/media/publi cations/171192-ID-teknologipendidikan-sebagaipembelajara.pdf.

Prasojo, Lantip Diat dan Riyanto. (2011). Teknologi Informasi Pendidikan. Yogyakarta: Gava Media.

Pribadi, Benny A. (2011). Peranan Teknologi Pendidikan Dalam Meningkatkan Kualitas 
Jurnal PINUS: Jurnal Penelitian Inovasi Pembelajaran, 7 (1), 2021, Dedy Ari Nugroho, Irawan Hadi Wiranata

$\begin{array}{lrr}\text { Pembelajaran." In } & \text { Optimalisasi } \\ \text { Peranan Teknologi } & \text { Pendidikan } \\ \text { Dalam Peningkatan } & \text { Kualitas } \\ \text { Pembelajaran, 2-3. } & \text { Padang: } \\ \text { Universitas Terbuka } & \text { Repository. } \\ \text { http://repository.ut.ac.id/7265/1/Pera } \\ \text { nan Teknologi } & \text { Pendidikan } \\ \text { dalam.pdf. }\end{array}$

Putro, Khamim Zarkasih, Muhammad Adly Amri, Nuraisah Wulandari, and Dedek Kurniawan. (2020). Pola Interaksi Anak dan Orangtua Selama Kebijakan Pembelajaran di Rumah. Fitrah: Journal of Islamic Education (FJIE), $\quad 1(1): \quad 126$. https://jurnal.staisumateramedan.ac.i d/index.php/fitrah/article/view/12/8.

Sudjana, Nana. (2007). Dasar-dasar Proses Belajar Mengajar. Bandung: Sinar Baru Algensindo..

Sugiyono. (2010). Metode Penelitian Pendidikan Pendekatan Kuantitatif, kualitatif, dan R\&D. Bandung: Alfabeta..

Sutopo, H.B. (2002). Metodologi Penelitian Kualitatif. Surakarta: Universitas Sebelas Maret Press.

Ubaedillah. (2015). Pendidikan Kewarga-negaraan (Civic Education): Pancasila, Demokrasi, dan Pencegahan Korupsi. Jakarta: Prenadamedia Group.

Uno, Hamzah B. \& Lamatenggo, Nina. Warsita, (2011). Teknologi Komunikasi \& Informasi Pembelajaran. Jakarta: Bumi Aksara.

Bambang. (2008). Teknologi Pembelajaran: Landasan \&Aplikasinya. Jakarta: Rineka. 